\title{
HIPERPRESIDENCIALISMO NA AMÉRICA LATINA
}

\author{
HYPER-PRESIDENTIALISM IN LATIN AMERICA
}

Carlos Bolonha*

Henrique Rangel $^{* *}$

Flávio Corrêa ${ }^{* * *}$

\begin{abstract}
RESUMO: o presente artigo adota como seu objeto os processos de fortalecimento do Poder Executivo, atendendo a uma delimitação latino-americana especificada pela metodologia. O principal problema constatado é o antagonismo existente entre esse fortalecimento e as mudanças constitucionais da Região no denominado “novo constitucionalismo latino-americano". Neste movimento, é característica a celebração e a apologia a mudanças constitucionais ocorridas na Região, a exemplo das Constituições equatoriana e boliviana que entraram em vigor, respectivamente, em 2008 e 2009. A figura do presidente, no entanto, não recebe o mesmo destaque que parlamentares e juízes. Seus governos, quando não tratados com indiferença, sofrem acusações de hiperpresidencialismo, apontado como "patologia institucional” na América Latina. Com isso, a hipótese desta pesquisa defende a existência de uma associação entre as mudanças constitucionais e o fortalecimento do Poder Executivo na Região. Partindo-se de um referencial teórico institucionalista, o objetivo do presente trabalho é oferecer uma crítica ao "novo constitucionalismo latino-americano", pois uma postura tão defensora de mudanças constitucionais na América Latina não pode desconsiderar o fortalecimento de seus presidentes associado àquele processo.
\end{abstract}

\footnotetext{
* Professor Adjunto, Vice-Diretor e Coordenador de Pesquisa da Faculdade Nacional de Direito (FND) da Universidade Federal do Rio de Janeiro (UFRJ). Professor Permanente do Programa de Pós-Graduação em Direito (PPGD) da Universidade Federal do Rio de Janeiro (UFRJ). Coordenador do Laboratório de Estudos Teóricos e Analíticos sobre o Comportamento das Instituições (LETACI). Bolsista de Produtividade em Pesquisa do Conselho de Desenvolvimento Científico e Tecnológico (CNPq). Diretor do Centro de Pesquisa e Documentação da Ordem dos Advogados do Brasil, Seccional do Rio de Janeiro (OAB/RJ).E-mail: bolonhacarlos@gmail.com

Mestrando em Teorias Jurídicas Contemporâneas pelo Programa de Pós-Graduação em Direito (PPGD) da Universidade Federal do Rio de Janeiro. Técnico Judiciário do Tribunal Regional do Trabalho da Primeira Região (TRT-1).E-mail: henriquerangelc@gmail.com

Graduado em Direito pela Universidade do Estado do Rio de Janeiro e em Engenharia Elétrica pela Universidade Federal Fluminense. Pesquisador convidado do Laboratório de Estudos Teóricos e Analíticos sobre o Comportamento das Instituições (LETACI), vinculado ao Programa de Pós-Graduação em Direito da Universidade Federal do Rio de Janeiro, integrando o Subgrupo de Pesquisa-4 (SGP-4). Auditor-Fiscal da Secretaria da Receita Federal do Brasil. Email: freceita@gmail.com
}

Este artigo foi elaborado no âmbito da disciplina Constitucionalismo Latino-Americano do Curso de Mestrado em Teorias Jurídicas Contemporâneas do Programa de Pós-Graduação em Direito da Universidade Federal do Rio de Janeiro, ministrado pelo Professor José Ribas Vieira. Os autores são membros do Laboratório de Estudos Teóricos e Analíticos sobre o Comportamento das Instituições (LETACI), coordenado pelo Professor Carlos Bolonha, vinculado à Faculdade Nacional de Direito (FND) e ao Programa de Pós-Graduação em Direito (PPGD) da Universidade Federal do Rio de Janeiro (UFRJ), financiado pelo Conselho Nacional de Desenvolvimento Científico e Tecnológico (CNPq), no âmbito do Edital Universal $n^{0}$ 14/2013, e pela Fundação Carlos Chagas Filho de Amparo à Pesquisa do Estado do Rio de Janeiro (FAPERJ), no âmbito da concorrência do Edital nº 41/2013, do Programa de Apoio a Grupos Emergentes de Pesquisa no Estado do Rio de Janeiro. 
PALAVRAS-CHAVE: América Latina. Desenhos Constitucionais. Hiperpresidencialismo. Mudança Constitucional. Novo Constitucionalismo Latino-Americano.

ABSTRACT: This article adopts the Executive branch's strengthening processes as its object. The methodology cares to the Latin America delimitation among others aspects. The main problem found is the antagonism between this strengthening and the constitutional change in the region according to the called "Latin American new constitutionalism". In this movement, the celebration of constitutional changes in the region is characteristic, likewise in the Bolivian and Ecuadorian Constitutions approval in 2008 and 2009. The president, however, does not receive the same weight as parliamentarians and judges. Their governments, when not treated with indifference, suffer accusations of hyperpresidentialism, labeled as a Latin America "institutional pathology". Thus, the hypothesis of this research argues the existence of an association between constitutional change and Executive branch's strengthening processes in the region. Beginning with an institutionalist theoretical framework, the aim of this work is to provide a critique of the "Latin American new constitutionalism", because its defense of Latin America constitutional changes should not ignore the strengthening of their presidents associated with that process.

KEYWORDS: Constitutional Change. Constitutional Design. Executive Branch. Latin America. Latin American New Constitutionalism.

\section{INTRODUÇÃO}

Ao longo dos últimos quinze anos, o direito constitucional na América Latina observou o desenvolvimento de alguns estudos que se difundiram como um "novo constitucionalismo latinoamericano". De forma semelhante ao denominado "neoconstitucionalismo", definir este recente pensamento constitucional parece ser um grande desafio. ${ }^{1}$ Esta dificuldade decorre de sua indeterminação quanto à origem acadêmica do modelo e quanto à falta de uniformidade de suas proposições. $^{2} \mathrm{O}$ suposto “novo constitucionalismo latino-americano”, apesar de tais dificuldades,

\footnotetext{
${ }^{1} \mathrm{O}$ desafio de se definir o que seria o "neoconstitucionalismo” pode ser ilustrado com o título da emblemática obra de Carbonell (CARBONELL, Miguel. Neoconstitucionalismo(s). 4ª ed. Madrid: Trotta, 2009).

${ }^{2}$ Não existe uma precisa e consensual correlação entre o "novo constitucionalismo latino-americano" e um autor, uma teoria, uma escola de pensamento, uma universidade ou um periódico em particular. Da mesma maneira, algumas das propostas de reformulação do direito constitucional aplicável à Região - oriundas de signatários diversos - podem parecer contraditórias ao sustentar a necessidade de aumentar a participação da população nas decisões do governo e, ao mesmo tempo, haver uma proteção mais radical de direitos fundamentais. Apesar de todo o debate existente entre a oposição ou articulação entre democracia e direitos fundamentais, estas proposições podem ser incompatíveis entre si, dependendo do marco teórico assumido pelo leitor, exceto quanto aos direitos fundamentais de natureza política. Ilustrando esta dificuldade, há árduos defensores deste posicionamento afirmando que "el nuevo constitucionalismo latinoamericano es un fenómeno surgido en el extrarradio de la Academia, producto más de las reivindicaciones de los movimientos sociales que de los professores de Derecho Constitucional”. Os mesmos autores complementam, quanto à falta de uniformidade, que "conseguientemente, carece de una cohesión y una articulación como sistema cerrado de análisis y proposición de un modelo constitucional” (PASTOR, Roberto Viciano; DALMAU, Rúben Martínez. ¿Se puede hablar de un nuevo constitucionalismo latinoamericano como corriente doctrinal sistematizada? 2010. Disponível em: <http://www.juridicas.unam.mx/wccl/ponencias/13/245.pdf>. Acesso em: 7 jun. 2014. p. 3-4). Na verdade, alegar que o "novo constitucionalismo latino-americano" não se trata de um sistema fechado representa uma estratégia de generalização. Por mais que se sustente não haver uma proposta específica de modelo constitucional, o que
} 
representa uma tentativa de reformular algumas dimensões do direito constitucional da Região. Entre as propostas mais recorrentes nestes estudos, é possível mencionar (a) uma revisão epistemológica, que relativiza a influência de categorias teóricas e conceituais externas, sobretudo eurocêntricas - o pós-colonialismo; (b) uma revisão sociopolítica, com o intuito de integrar segmentos culturais e sociais anteriormente excluídos dos processos constituinte e governamental; e (c) uma revisão jurídico-normativa, valorizando-se o intérprete como protagonista de uma era em que os direitos alcançam maior eficácia.

Alguns temas recebem maior ou menor destaque no "novo constitucionalismo latinoamericano", sendo comum se valorizar a participação política e o papel dos juízes no regime democrático. A figura do Poder Executivo e, particularmente, o presidente, são negligenciados, e mesmo combatidos, por este modelo - e isto constitui o problema central do presente trabalho. Quando os estudos do “novo constitucionalismo latino-americano" se voltam ao Executivo, costuma se utilizar o termo "hiperpresidencialismo", devido à influência das críticas formuladas por Carlos Santiago Nino. ${ }^{3}$ Em muitas ocasiões, esse termo é empregado com um viés depreciativo, atribuindo ao presidente um exercício ilegítimo de seus poderes constitucionais. ${ }^{4} \mathrm{O}$ hiperpresidencialismo, quando abordado, é reconhecido como um problema institucional e um obstáculo aos objetivos deste "novo constitucionalismo”, ou mesmo um motivo para seu surgimento. Diante desta relação de indiferença ou antagonismo, é possível afirmar que o "novo constitucionalismo latino-americano” tenta, em geral, afastar-se do presidente. A partir desta relação problemática, o presente artigo adota o fortalecimento do Poder Executivo na América Latina como seu objeto de investigações.

O mencionado modelo de constitucionalismo, como sugere sua própria denominação, preza por mudanças constitucionais. Acontecimentos como a promulgação de uma nova constituição na América Latina são comemorados como conquistas políticas entre os signatários do

se pretende é exportar a ideia para o maior número de países da Região, e tal abertura seria o instrumento facilitador de sua entrada.

${ }^{3}$ A maior parte dos textos se reporta à contribuição crítica de Carlos Santiago Nino como precursor da terminologia “hiperpresidencialismo” no direito constitucional (NINO, Carlos Santiago. Fundamentos de derecho constitucional: análisis filosófico, jurídico y politológico de la práctica constitucional. Buenos Aires: Astrea, 1992).

${ }^{4}$ Antonio Hernández, por exemplo, identifica o hiperpresidencialismo como uma "patologia institucional”: “Para nosotros este fenómeno se caracteriza por la concentración del poder en el presidente, mas allá de las competencias fijadas por la Constitución, en desmedro de la división y equilibrio de los poderes y de los principios de la democracia constitucional. Debemos a Carlos Santiago Nino el más agudo y profundo estudio de esta grave patología institucional, que produce inconmensurables efectos negativos para el sistema político y jurídico y para una sociedad abierta porque impide la vigencia de una democracia deliberativa, en su obra Fundamentos de Derecho Constitucional, Buenos Aires, Astrea, 1992, capítulo III, donde expuso el tema con visión interdisciplinaria. También se detuvo en la caracterización del carácter corporativo de nuestro hiperpresidencialismo, que en nuestros días se manifiesta con particular fuerza.” (HERNÁNDEZ, Antonio. A Tres Lustros de la Reforma Constitucional de 1994. Revista de la Faculdad de Derecho de México, Vol. 60, 254, 2010. p. 186). 
“novo constitucionalismo latino-americano”. Esta euforia acadêmica que emerge da aprovação de novas constituições ou grandes processos de reforma constitucional na América Latina, bem como o próprio nome com que se convencionou chamar este constitucionalismo, são fatores que permitem qualificá-lo como uma apologia à mudança constitucional.

Com base neste quadro, o presente artigo, relacionando ambos os fenômenos, formula a seguinte hipótese: os processos de mudança constitucional por que tem passado a América Latina estão associados ao fortalecimento dos presidentes latino-americanos. ${ }^{5}$

Para defender a hipótese acima, este artigo parte de uma demarcação teórica institucional que concentra seus esforços na análise do presidente em uma concepção de governo denominada Estado administrativo moderno. Neste âmbito, tem se desenvolvido uma perspectiva crítica à tradicional separação de poderes que restou denominada pós-madisonianismo. Talvez sua obra mais emblemática seja o livro de Eric Posner e Adrian Vermeule, The Executive Unbound, em que se faz uma forte articulação entre a figura do presidente, no contexto norte-americano, e os processos de mudança constitucional. ${ }^{6}$

A metodologia, por sua vez, estabelece critérios delimitadores e parâmetros responsáveis por guiar as análises. Quanto à delimitação, o critério temporal abrange o período de 1811-2014. ${ }^{7}$ Espacialmente, são avaliados os governos latino-americanos com restrições justificáveis. ${ }^{8}$ No

\footnotetext{
${ }^{5}$ A relação entre mudança constitucional e fortalecimento do Poder Executivo poderia ser abordada em uma única obra, mas isso tornaria o texto excessivamente extenso. Portanto, o presente trabalho focará apenas o fortalecimento do Poder Executivo, enquanto o objeto mudança constitucional será tratado separadamente em outro artigo, já submetido à avaliação de revista diversa, denominado Mudança Constitucional na América Latina. Neste artigo, foi elaborado um indicador para comparar como alguns países latino-americanos passam por mudanças constitucionais (Índice de Mudança Constitucional - IM-CONST), baseado nos seguintes parâmetros: (i) o número de constituições e reformas constitucionais em larga-escala aprovadas em determinado país desde sua independência política; e (ii) o número de emendas aprovadas em relação à constituição atualmente vigente naquele país latino-americano. Ambos os trabalhos representam resultados da mesma pesquisa.

${ }^{6}$ A relação entre presidente e mudança constitucional, especificamente, concentra-se no segundo capítulo da obra POSNER, Eric; VERMEULE, Adrian. The Executive Unbound: after the madisonian republic. New York: Oxford University Press, 2010.

${ }^{7}$ A primeira justificativa para o marco inicial do critério metodológico é o reconhecimento do "Reglamento para el Arreglo de la Autoridad Ejecutiva Provisoria de Chile de 1811” como primeiro documento formal com natureza constitucional aprovado por um governo liderado por autoridades latino-americanas, em meio ao conturbado processo histórico da Independência da América Espanhola (1808-1829). A segunda justificativa para a abrangência do critério decorre de um dos objetos adotados pela pesquisa como um todo: mudança constitucional. Trata-se de matéria que, naturalmente, requer uma delimitação temporal prolongada, uma vez que mudanças constitucionais se expressam por meio de acontecimentos com relativa dispersão na história política do País.

${ }^{8}$ A pesquisa, espacialmente, conta com três restrições espaciais justificáveis e que visam conferir maior precisão e confiabilidade a seus resultados. Em primeiro lugar, a pesquisa não abrange os países inseridos na região do Caribe, sujeita a circunstâncias sociais, políticas e, principalmente, econômicas que diferem do restante da América Latina. Em segundo lugar, os contextos econômico, político e, principalmente, social da América Central difere do restante da Região e exige que restrições sejam impostas. Em terceiro lugar, o presente cenário político da Venezuela indica uma necessidade de exclusão. Embora alguns autores identifiquem o hiperpresidencialismo no governo venezuelano, somente servirão aos propósitos do presente trabalho países inseridos em um regime cujo caráter democrático não seja tão questionável. Como o marco teórico eleito parte da perspectiva do Estado administrativo moderno - que não deixa
} 
recorte material, são considerados constituições e processos de reforma constitucional - em larga ou pequena escalas -, bem como qualquer documento político com o fim de estruturar os Estados latino-americanos abrangidos pelo critério espacial. Além destes recursos, ao recorte material integram estudos e pesquisas bibliográficos das ciências jurídica e política pertinentes ao objeto selecionado e dados estatísticos. ${ }^{9}$ Por fim, as análises se norteiam por parâmetros que podem ser cruzados ou isoladamente considerados: (i) fortalecimento de seus poderes constitucionais, compreendidos em relação às competências e às atribuições estabelecidas em norma constitucional; (ii) fortalecimento diante da configuração política, avaliando-se a relação mantida com o Legislativo em nível federal em cada país latino-americano; e (iii) apoio popular ao governo, recorrendo-se a pesquisas que indicam o quanto a figura do presidente detém popularidade para implementar suas medidas e conduzir seus planos políticos. A partir destes parâmetros será estruturado um índice, desenvolvido para os propósitos da presente pesquisa e observando especialmente as propriedades latino-americanas, que viabilizará considerações objetivas e correlacionadas entre tais países: o Índice de Fortalecimento do Executivo (IF-EXEC).

O objetivo deste trabalho é demonstrar ao "novo constitucionalismo latino-americano" como a relação entre presidentes e mudança constitucional pode ser mais estreita do que imaginam seus signatários.

\section{O PRESIDENTE NA TEORIA}

No século XX, a América Latina foi severamente impactada por dois eventos históricos: o primeiro, a crise política dos anos de 1970 e as graves violações aos direitos humanos ao longo desse período; o segundo, a crise econômica e social que se seguiu à aplicação de programas de ajuste estruturais nos anos de 1990. Em reação às consequências desses fatos, a Região foi palco de importantes alterações na ordem constitucional com vistas à substituição de regimes ditatoriais por governos democráticos, à criação de barreiras legais contra as transgressões aos direitos humanos e à instituição de programas de cunho social em resposta aos efeitos dos ajustes neoliberais. As novas constituições reforçaram os compromissos sociais que emergiram posteriormente à Constituição

de ser democrático de direito -, o exercício dos poderes constitucionais dos dois últimos presidentes venezuelano é suficientemente duvidoso para justificar a exceção. Neste sentido, é possível resumir o critério espacial indicando que a pesquisa abrange a América do Sul, com a exceção de Venezuela e dos países que não compartilham da origem linguística latina, e o México.

${ }^{9}$ Quanto aos dados estatísticos, há especial destaque para as informações disponibilizadas pelo Informe 2013 da Corporación Latinobarómetro, complementado por atualizações e revisões que se mostrem necessárias ou oportunas (CORPORACIÓN LATINOBARÓMETRO. Informe 2013. Santiago de Chile: Corporación Latinobarómetro, 2013. Disponível em: <http://www.latinobarometro.org/documentos/LATBD_INFORME_LB_2013.pdf>. Acesso em: 7 jun. 2014). 
mexicana de 1917. No entanto, permaneceu intocada a tradicional organização vertical do poder (GARGARELLA, 2013, p. 149).

A partir de um constitucionalismo inovador que se alastrou na América Latina desde a década de 1980, conferiu-se status constitucional a direitos humanos que já tinham sido objeto de tratados internacionais celebrados para proteger populações locais das massivas violações praticadas ao tempo das ditaduras. Contraditoriamente, as reformas constitucionais empreendidas na América Latina mantiveram a matriz de concentração da autoridade intacta, alinhando-se a um esquema institucional consentâneo com a transferência de poderes legislativos ao Executivo e a concessão de amplos poderes emergenciais ao presidente da república. Em casos mais extremos, esse hiperpresidencialismo regional, seja da esquerda ou da direita política, assumiu formas populistas ou incorporou a tendência de cooptar as autoridades dos demais ramos ou de permanecer indefinidamente no poder; nesse caso, valendo-se das reeleições sucessivas - muitas vezes articuladas por meio de emendas constitucionais.

Com efeito, podem surgir focos de tensão no desenho institucional, em virtude da implantação de projetos que, ao mesmo tempo, concentram poderes no presidente da república e constitucionalizam direitos fundamentais. Isto porque a expansão de direitos fundamentais pode acarretar limitação dos poderes estatais. Tal perspectiva assinala que os direitos fundamentais implicam restrição à ação das autoridades do governo. Os dispositivos constitucionais que instituem e organizam os poderes do Estado e os que constitucionalizam direitos não se encontram isolados em contextos jurídicos incomunicáveis. ${ }^{10}$

Aproximando-se de uma perspectiva que aborda mecanismos compensatórios no sistema constitucional, o fortalecimento do presidente da república poderia ser uma forma de compensação à expansão de direitos (GARGARELLA, 2013, p. 158). Essa ideia parte do pressuposto de que o sistema constitucional é fruto do embate entre forças políticas que fazem concessões recíprocas em busca de um equilíbrio. Por esse prisma, as seções das constituições não são autônomas nem indiferentes umas com as outras. Ao contrário, entre elas haveria uma fricção que deriva dos conflitos entre tendências contrapostas e atuantes no debate democrático-constitucional, refletindo as posturas que, de um lado, propugnam o crescimento dos poderes do congresso, a independência judicial, maior participação política dos cidadãos, a constitucionalização de direitos sociais, e, de outro lado, o incremento dos poderes presidenciais e a reeleição, por exemplo. Por esse viés, enquanto algumas cláusulas constitucionais transferem poderes ao Executivo, outras mudanças

\footnotetext{
${ }^{10}$ Este é um posicionamento fortemente defendido em GARGARELLA, Roberto. Latin american constitutionalism, 1810-2010. The engine room of the Constitution. New York, NY: Oxford University Press, 2013.
} 
concedem aos indivíduos o poder de controlar seus representantes eleitos. No entanto, Gargarella sustenta que os defensores da teoria da compensação partem do princípio de que há uma relação igualitária entre os diferentes setores das disposições constitucionais (GARGARELLA, 2013, p. 159). O argumento trazido por este teórico, ao afirmar a existência desta desigualdade, reporta-se à dificuldade de compensações se lançarem sobre as normas constitucionais dedicadas à organização dos poderes - o que ele defende ser a “casa de máquinas” das constituições. Em princípio, isso esclareceria a razão de o hiperpresidencialismo ainda existir na América Latina após o reconhecimento de direitos e garantias fundamentais em suas constituições.

Tradicionalmente, afirma-se que os poderes são estruturados de uma forma que possam contar com instrumentos para promover ou para refrear as reformas propostas, conforme suas próprias ambições. Entretanto, no contexto histórico da América Latina, o Executivo tornou-se primus inter pares dentro da organização de poder, desfrutando de uma posição que lhe confere privilégios na estrutura constitucional. Contudo, uma linha teórica otimista, por sua vez, salienta que um sistema de autoridade concentrada é condição necessária para assegurar direitos sociais, pois essas conquistas sempre estiveram associadas, na Região, a contextos caracterizados pelo binômio "poderes concentrados no Executivo e hegemonia parlamentar", e não a ambientes institucionais onde vigora um presidencialismo fraco com pluralismo legislativo. Em divergência, Gargarella adverte que o hiperpresidencialismo dominante na América Latina é compatível com os mais variados resultados, em termos de direitos constitucionais (GARGARELLA, 2013, p. 160). Ou seja, o hiperpresidencialismo latino-americano tanto pode promover a implementação desses direitos como pode ser decisivo para a violação. ${ }^{11}$

Ultimamente, argumentos fundados nas ideias de Schmitt explicitam certa repulsa à teoria madisoniana que advoga um sistema equilibrado de freios e contrapesos, levando em conta o fato de que o mundo moderno está imerso em problemas que requerem soluções urgentes, dependentes de uma dinâmica institucional célere e efetiva. A velocidade necessária à emissão de respostas compatíveis com a multiplicidade das demandas presentes não se satisfaz por essa óptica, exceto no interior de um arranjo que concentra poderes no único ramo que dispõe de capacidade técnica e operacional para o atendimento das exigências postas pela modernidade: o Executivo. Diante disso,

\footnotetext{
${ }^{11}$ Nesse sentido, Gargarella (2013) observa que o hiperpresidencialismo não ensejará um resultado invariável em termos de direitos. Em primeiro lugar, foram introduzidos, com a chegada de regimes democráticos que sucederam ditaduras militares, em versões mais moderadas de presidencialismo, fortes sistemas de proteção de liberdades individuais. Em segundo lugar, alguns regimes autoritários na Região instituíram direitos sociais enquanto limitavam outras espécies de direitos, a exemplo do de Getúlio Vargas, no Brasil, e de Juan Perón, na Argentina. Por fim, o hiperpresidencialismo também serviu à desmontagem do welfare state, em governos como o de Carlos Menem, na Argentina, e o de Collor de Melo, no Brasil.
} 
muitos países - não somente na América Latina - optaram por delegar autoridade legislativa ao presidente da república, ao mesmo tempo que expandiram os poderes emergenciais do Executivo, mediante reformas constitucionais ou legais que visavam atender a intervenções em momentos de crises. Essa opção é consistente com a urgência que só o Executivo pode combater, já que o Judiciário e o Legislativo padecem de um déficit de capacidades institucionais e de uma assimetria informacional que os impede de atuar em tais situações. ${ }^{12}$

Os poderes emergenciais do presidente da república deram ensejo à criação de “presidências imperiais”, assim chamadas porque dotadas de uma ampla capacidade de atuação. ${ }^{13}$ Os defensores dessa corrente se baseiam na teoria schmittiana, segundo a qual o temor gerado pela visão de um Executivo poderoso é explicado a partir de um típico legalismo liberal, que faz diferenciação entre falta de controle legal sobre o presidente e ausência completa de controle. ${ }^{14}$ Ao contrário do que sustentam os tiranofóbicos, alarmistas de que a ausência de meios legais de controle do Executivo conduza necessariamente à ditadura, o presidente da república, em nosso tempo, está sujeito a um controle político e popular que são mais intensos que os tradicionais freios e contrapesos. ${ }^{15}$ Essas instâncias de fiscalização, que se valem das facilidades trazidas pela revolução tecnológica para propiciar mecanismos de menor custo para as críticas dos cidadãos às autoridades, podem, por exemplo, obstar a reeleição. De acordo com tal posição, o paradigma madisoniano de freios e contrapesos está superado, pois fatos como as emergências e as delegações conduzem o Executivo a um nível de fortalecimento sem o qual a governabilidade no contexto contemporâneo restaria severamente prejudicada.

\section{FORTALECIMENTO DO PODER EXECUTINO NA AMÉRICA LATINA}

O objeto específico desta pesquisa foi analisado de acordo com três aspectos distintos. Em primeiro lugar, o fortalecimento do Poder Executivo na América Latina está relacionado à base normativa dos poderes constitucionalmente estabelecidos. A expressa previsão de competências e atribuições é o primeiro passo para que se observem traços de hiperpresidencialismo em determinado governo. Em segundo lugar, a configuração política de cada país será determinante ao

\footnotetext{
${ }^{12}$ Acerca das capacidades institucionais, Cf. SUNSTEIN, Cass; VERMEULE, Adrian. Interpretation and Institutions. Chicago Public Law \& Legal Theory Working Paper Series, N. 28, 2002. Quanto ao conceito de assimetria informacional, Cf. POSNER \& VERMEULE, 2010.

${ }^{13}$ Quanto ao surgimento e a caracterização de "presidências imperiais" na História Contemporânea, Cf. SCHLESINGER, JR., Arthur. The Imperial Presidency. New York, NY: The Mariner Books, 2004.

${ }^{14}$ O termo legalismo liberal é definido em POSNER \& VERMEULE, 2010, como forma de conjugação de distintos segmentos teóricos que convergem na crença de que mecanismos de checks and balances seriam efetivos no contexto atual.

${ }^{15}$ Esta é a tese central de POSNER \& VERMEULE, 2010.
} 
efetivo desempenho da autoridade política do presidente e de seus agentes subordinados. Por um lado, uma conjuntura política favorável ao Executivo lhe permitirá exercer poderes de facto de fundamentação normativa indeterminada, quando não inexistente ou duvidosa. Por outro lado, um contexto político prejudicial poderá impedir o pleno desempenho de poderes cuja base normativa seja clara e de tradicional reconhecimento - por exemplo, mecanismos submajoritários ou coalizões políticas adversas. Em terceiro lugar, a teoria pós-madisoniana retratou a relevância do apoio popular ao governo para o presidente implementar as mudanças pretendidas. Entre tais aspectos, é indispensável esclarecer que, dependendo do país avaliado, algum fator pode ser mais determinante para caracterizar seu hiperpresidencialismo, mas, devido a razões metodológicas, os dados não poderiam ser submetidos a análises não uniformes.

No geral, a América Latina é historicamente caracterizada por uma organização de Estado que atribui generosos poderes constitucionais à figura do presidente. Uma análise das constituições latino-americanas vigentes, no entanto, revela que alguns destes países se destacam: Peru, Brasil e Equador. Esses três países concentram fortes poderes no presidente.

A Constituição Política do Peru de 1993 foi aprovada sob as circunstâncias de um regime autoritário que durou dez anos, liderado pelo nipo-peruano Alberto Fujimori (1990-2000). Com isso, o presidente conta com fortes poderes regulamentares (art. 118 , 8) e de veto total e parcial, admitindo-se contrapropostas ao Congresso sob o quórum de maioria absoluta (art. 108º), além de prerrogativas formais de agenda ao encaminhar mensagens ao Congresso, em qualquer época, indicando quais seriam as reformas necessárias ou convenientes ao presidente (art. 118 ${ }^{\circ}$, 7). Associado a esses fortes poderes constitucionais, o presidente peruano detém o mesmo poder geral de iniciativa legislativa que o Congresso, não havendo qualquer limitação em razão da matéria (art. $107^{\circ}$ ), também podendo expedir decretos de urgência com força de lei em matéria econômica e financeira, utilizando-se como critério legal limitador desta faculdade o indeterminado conceito do interesse nacional (art. $\left.118^{\circ}, 19\right)$.

A Constituição da República Federativa do Brasil de 1988 foi promulgada em um contexto de redemocratização do País, sendo-lhe atribuído um epíteto de “Constituição Cidadã”. Apesar dos auspícios de um regime de governo renovado, a tradição de presidencialismo imperial não se afastou do período pós-ditatorial brasileiro. O Executivo, no Brasil, detém poderes constitucionais capazes de se destacar na região latino-americana, tradicionalmente hiperpresidencialista. O presidente brasileiro não somente conta com poderes regulamentares para expedir decretos (art. 84, IV), como também possui competência formal para expedir o que a doutrina convencionou chamar de “decretos autônomos” (art. 84, VI, a). Assim como no Peru, o Brasil atribui poder de veto parcial 
ou total ao presidente e uma das condições legais impostas como justificativa ao veto inconstitucionalidade e interesse público - é significativamente subjetiva (art. 66, $§ 1^{\circ}$ ). Além de escolher livremente entre os ministros de Estado que lhe prestarão auxílio, o presidente brasileiro tem poder de indicar ministros ao Supremo Tribunal Federal, o Procurador Geral da República, o Advogado-Geral da União, o presidente do Banco Central do Brasil - que goza de status de ministro -, conselheiros do Tribunal de Contas da União (art. 84, XIV a XVI), entre outras autoridades da Administração Pública. Entre as disposições que regem o processo legislativo brasileiro, o presidente possui competência para propor emenda à Constituição (art. 60, II) e iniciativa legal em matérias como organização administrativa e judiciária, serviço público, tributos e orçamento público (art. 61, §1 $1^{\circ}$ ). Porém, essas não são as competências legislativas que mais fortalecem o presidente brasileiro. As chamadas medidas provisórias são espécies normativas com força de lei e que produzem efeitos imediatos. Em tese, existem limitações em razão da matéria para a edição de medidas provisórias, além de haver dois requisitos legais que lhe são pressupostos: urgência e relevância da matéria (art. 62). As medidas provisórias não somente representam uma poderosa competência legislativa do Executivo brasileiro, mas também se expressam como um importante poder de agenda, pois, contados quarenta e cinco dias de sua publicação, a medida entra em regime de urgência de votação, sobrestando toda a pauta de deliberações do Congresso até que reste sanado o atraso (art. 62, $\left.\S 6^{\circ}\right)$.

De todas as constituições latino-americanas em vigência apreciadas, a equatoriana parece ser a que mais atribui poderes ao Poder Executivo. A Constituição da República do Equador de 2008 foi elaborada por uma assembleia constituinte no interior do governo de Rafael Correa (20072014) e levada a referendo popular. O partido de Correa, Alianza País, era maioria na assembleia constituinte que redigiu a atual carta política equatoriana, o que conduziu a uma forte assimetria nos poderes constitucionais. ${ }^{16}$ Nos países frequentemente reputados como hiperpresidencialistas, o presidente conta, em geral, com poderes de veto total ou parcial, de regulamentar a lei via decreto, e de iniciar o processo legislativo, mesmo que limitada esta prerrogativa quanto à matéria. De fato, o presidente equatoriano possui poder regulamentar, também podendo vetar iniciativas legislativas, cabendo-lhe propor nova redação cuja reprovação pelo Congresso depende do quórum qualificado

\footnotetext{
16 "Una particularidad de las reformas institucionales citadas radica en que se dieron en un contexto distinto al que existió durante las dos Constituciones previas (1977-78; 1997-98). Por una parte, el proceso constituyente fue auspiciado por el gobierno en funciones; es decir, no precedió a la elección de un nuevo gobierno y, por otra, el partido oficialista mantuvo una representación mayoritaria en la Asamblea Constituyente. Trabajos previos realizados para la región sugieren que este predominio gubernamental o asimetría en el balance de fuerzas tiende a incrementar el poder presidencial (hiper presidencialismo), reduciendo los incentivos que tiene la oposición para consolidar el nuevo pacto constitucional (CORRALES, 2008 apud BASSABE-SERRANO, Santiago. Ecuador: Reforma Constitucional, Nuevos Actores Políticos y Viejas Práticas Partidistas. Revista de Ciência Política, Vol. 29, nº 2, 2009. p. 388).
} 
de dois terços. O que se destaca, todavia, são as inesperáveis competências exclusivas para influir em planificação econômica, orçamento público, regime tributário, políticas monetária, cambiária e creditícia, controle de setores estratégicos da economia e transferência de receitas aos governos subnacionais. ${ }^{17}$ Também é preciso ressaltar que, no Equador, não cabe ao Congresso convocar consultas públicas, e sim ao presidente, um poder constitucional que pode conduzir o regime democrático a práticas tipicamente cesaristas. Enquanto Peru e Brasil combatem questões urgentes por, respectivamente, decreto e medidas provisórias, a Constituição equatoriana somente prevê competência presidencial para iniciar processo legislativo urgente em matéria econômica - o que poderia parecer pouco se já não contasse com tantas competências exclusivas em matérias tributária, orçamentária, monetária, cambiária, creditícia, entre outras.

Quanto ao segundo aspecto do fortalecimento do Poder Executivo na América Latina, qual seja, a configuração política favorável ao desenvolvimento do hiperpresidencialismo, existem disparidades na Região. Em tese, os presidentes que contam com poderes constitucionais mais acentuados tendem a desempenhar uma performance política preponderante em relação ao Legislativo - como é o caso de Brasil e Equador. Essa ideia, no entanto, não se confirma em todos os casos. Nem todo país em que o presidente possui fortes poderes constitucionais observa um efetivo governo hiperpresidencialista em termos de performance política - é o caso do Peru desde 2000 -, enquanto algumas presidências supostamente fragilizadas exploram circunstâncias políticas favoráveis para se apresentar de maneira destacadamente fortalecida - Chile, Argentina e México.

Brasil e Equador reproduzem o resultado da análise de poderes constitucionais neste quesito. Desse modo, é possível afirmar que, embora por razões distintas, os poderes constitucionalmente previstos nesses países são efetivamente exercidos por suas presidências. No Brasil, Sérgio Abranches alerta que a combinação de variáveis políticas, como multipartidarismo, representação proporcional, federalismo, bicameralismo e presidencialismo, poderia conduzir a um dilema de governabilidade. Abranches teve sucesso ao cunhar o termo "presidencialismo de coalizão” para definir o modelo político brasileiro, embora sua visão pessimista tenha se

\footnotetext{
17 "La nueva Constitución refuerza e incrementa el predominio del presidente sobre los otros Poderes del Estado. Formalmente se concede al Ejecutivo la capacidad exclusiva para influir sobre la planificación económica (art. 279), elaborar el Presupuesto del Estado (arts. 291 al 293), establecer el régimen tributario (art. 299), determinar la política monetaria, cambiaria y crediticia (art. 300), decidir sobre el control de los sectores estratégicos (arts. 311, 314 y 315) y regular las transferencias a los gobiernos subnacionales (art. 157). Estas facultades vienen a complementar las ya existentes para legislar por decreto, convocar consultas populares y vetar legislación. En este punto, la literatura especializada señala que fuertes poderes presidenciales como los arriba anotados se otorgan para compensar la ausencia de un respaldo político del partido gobiernista en la legislatura (Mainwaring y Shugart 1997; Morgenstern y Nacif, 2002). Sin embargo, en el caso ecuatoriano el nuevo estatus mayoritario que ganó AP tanto en la Asamblea Constituyente como en el cuerpo legislativo de transición formado a partir de octubre de 2008, tornan a la nueva Constitución en una de las más presidencialistas de la región, junto con - o más presidencialista que - la venezolana de 1999 (Mejía Acosta, 2008)” (BASSABE-SERRANO, 2009, p. 388-9).
} 
relativizado na ciência política por autores como Argelina Cheirub Figueiredo, Fernando Limongi e Fabiano Santos, defendendo o sucesso do presidente em articular os partidos como meio para implementar seus planos políticos. ${ }^{18}$ No Equador, por sua vez, o Congresso é uma instituição política enfraquecida por ter suas competências esvaziadas notadamente pela atual Constituição. Com isso, faltam-lhe normas constitucionais reservando autoridade para o exercício de um papel que supere sua marginalidade ao sistema político equatoriano. Ao contrário destes dois países, o Peru passou por uma profunda mudança política com o fim da ditadura de Fujimori em 2000 e, apesar de o presidente deter poderosas prerrogativas constitucionais, este tem atuado com moderação se comparado ao restante da Região.

Existem estudos sobre o presidencialismo na América Latina que assinalam a possibilidade de o Executivo se destacar na performance política sem, contudo, possuir acentuados poderes constitucionais. Entre os trabalhos mais influentes, Shugart e Carey (1992) desenvolveram uma pesquisa comparativa entre Executivo e Legislativo nos países latino-americanos, apontando-se algumas assimetrias entre os poderes e classificando-se alguns presidentes como forte ou fraco de acordo com os poderes constitucionalmente previsto. Essa pesquisa foi atualizada por Mainwaring e Shugart (1997), passando-se a analisar a efetiva atividade institucional dos presidentes nos países latino-americanos, não somente em termos de disposições constitucionais. Um dos resultados obtidos é que a primeira sondagem havia se equivocado quanto à real força do Executivo no Chile e

\footnotetext{
${ }^{18}$ Termo originalmente cunhado por Sérgio Henrique Abranches: “Apenas uma característica, associada à experiência brasileira, ressalta como uma singularidade: o Brasil é o único país que, além de combinar a proporcionalidade, o multipartidarismo e o 'presidencialismo imperial', organiza o Executivo com base em grandes coalizões. A esse traço peculiar da institucionalidade concreta brasileira chamarei, à falta de melhor nome, 'presidencialismo de coalizão', distinguindo-o dos regimes da Áustria e da Finlândia (e a França gaullista), tecnicamente parlamentares, mas que poderiam ser denominados de 'presidencialismo de gabinete' (uma não menos canhestra denominação, formada por analogia com o termo inglês cabinet government). Fica evidente que a distinção se faz fundamentalmente entre um 'presidencialismo imperial', baseado na independência entre os poderes, se não na hegemonia do Executivo, e que organiza o ministério como amplas coalizões, e um presidencialismo 'mitigado' pelo controle parlamentar sobre o gabinete e que também constitui este gabinete, eventual ou freqüentemente, através de grandes coalizões. O Brasil retorna ao conjunto das nações democráticas, sendo o único caso de presidencialismo de coalizão." (ABRANCHES, Sérgio. Presidencialismo de coalizão: o dilema institucional brasileiro. Dados - Revista de Ciências Sociais, Vol. 31, 1, 1988). Quanto aos trabalhos da ciência política que relativizam o "dilema institucional” de Sérgio Abranches: "Esse desempenho tem marcado de forma tão preponderante o recente padrão de relações entre o executivo e o legislativo no Brasil que parte da literatura mencionada considerou necessário redefinir o conceito de presidencialismo de coalizão, cunhado por Sérgio Abranches em 1988, quando os receios sobre o funcionamento do sistema político resultante da transição democrática ainda eram generalizados. Figueiredo e Limongi (1999; 2003) e (Santos, 2003), ao lado de outros estão entre os autores que mais contribuíram para mudar os rumos do debate sobre a questão, mostrando que diferente da tese original que elencava um conjunto de fatores institucionais causadores de risco permanente de instabilidade política, especialmente, de paralisia decisória derivada de relações potencialmente conflituosas entre o executivo e o legislativo, o país teria consolidado um sistema político que, semelhante ao parlamentarismo, asseguraria não apenas a capacidade do executivo de ter os seus projetos de leis e de políticas aprovados pelo parlamento, mas também o domínio quase absoluto dos presidentes sobre a agenda política do parlamento.” (MOISÉS, José Álvaro. O desempenho do Congresso Nacional no presidencialismo de coalizão. In: MOISÉS, José Álvaro (Org.). O Papel do Congresso Nacional do Presidencialismo de Coalizão. Rio de Janeiro, RJ: Konrad-Adenauer-Stiftung, 2011. p. 8).
} 
na Argentina. ${ }^{19}$

Pela Constituição Política da República do Chile de 1980, o Executivo não pareceria estar fortalecido, pois não se estabeleceram muitos poderes normativos ao presidente. Ao contrário, foram ampliados os poderes de veto de minorias políticas com os critérios supermajoritários das “leis orgânicas constitucionais”, que sofrem controle preventivo de constitucionalidade pelo Tribunal Constitucional, e das "leis de quórum qualificado". Além disso, o controle preventivo de constitucionalidade dos decretos supremos do presidente pelo Tribunal Constitucional chileno é marcante, uma vez que os recursos de inconstitucionalidade podem ser ajuizados por um quarto dos parlamentares em exercício e, se aceita sua tramitação, suspendem automaticamente a eficácia de tais atos normativos até sua apreciação definitiva - medida usada com frequência pela oposição aos governos de Frei Ruiz-Tagle e de Ricardo Lagos (HUNEEUS, 2012, p. 889). Alguns poderes constitucionais de indicar importantes agentes do governo, comuns na Região, foram transferidos ao Senado ou ao então instituído Serviço Civil (HUNEEUS, 2012, p. 889-90). A partir deste quadro político crítico posterior à ditadura de Pinochet, o Chile desenvolveu uma sistemática nos moldes do presidencialismo de coalizão brasileiro. Desde o governo de Patrício Aylwin (1990-1994), devido a problemas de governabilidade herdados da transição do regime autoritário, coalizões partidárias permitiram que o presidente chileno obtivesse uma performance política, em geral, bemsucedida. Segundo Carlos Huneeus, os dois primeiros presidentes chilenos após Pinochet - Aylwin e Ruiz-Tagle - investiram em uma estratégia política de descentralização decisória a seus ministros, o que, associado a coalizões de partidos, confere forte credibilidade à figura do presidente (HUNEEUS, 2012). Uma vez fortalecida a influência política do presidente chileno e articuladas suas coalizões partidárias, esta descentralização foi reduzida nos governos de Ricardo Lagos e Michelle Bachelet.

Os recentes governos democráticos na Argentina têm sido compreendidos pelos analistas como modelos de predominância presidencial. Embora tais afirmações sejam gerais, abrangendo os mandatos de Raúl Alfonsín (1983-1989) até Cristina Kirchner (2007-2014), é no decênio de Carlos

\footnotetext{
19 "Boa parte do livro de Shugart e Carey (1992) trata da análise dos recursos de poder do presidente detalhados na Constituição, especialmente os relacionados com o Congresso. Essa era uma visão que não podia explicar a diversidade de fontes da autoridade e poder presidencial e que desconhecia a existência de instituições alheias a ela, que também constituíam uma fonte de limitação do seu poder. Em um trabalho posterior escrito com Mainwaring (Mainwaring e Shugart, 1994), Shugart reconheceu que 'uma comparação dos poderes constitucionais não proporciona informação sobre o quanto eles são poderosos na realidade. No entanto, repetiram o procedimento, mostrando o presidente da Argentina, Carlos Menem (1989-1999), como um dos presidentes fracos entre os incluídos na sua pesquisa, sendo na prática um dos mais poderosos na região (Mainwaring e Shugart, 1994: 409). Também o presidente do Chile em 1990 foi considerado com menos poder que o mandatário anterior ao regime militar (Mainwaring e Shugart, 1994: 409), uma conclusão errônea porque a Constituição de 1980 estabeleceu um 'hiperpresidencialismo', feito sob medida para o general Pinochet, que estava disposto a continuar no cargo após 1990.” (HUNEEUS, Carlos. Variedades de Governos de Coalizão no Presidencialismo. Chile, 1990-2000. Dados - Revista de Ciências Sociais, Vol. 55, 4, 2012. p. 881-2).
} 
Menem (1989-1999) que o hiperpresidencialismo argentino se revela mais intenso. ${ }^{20}$ Esse destaque do hiperpresidencialismo no governo de Menem deriva de um motivo em particular: os decretos de necessidade e urgência. O contexto econômico vivenciado pela Argentina naquele período era crítico e o presidente utilizou tais circunstâncias emergenciais para justificar o exercício de um poder que, à época, nem sequer detinha base constitucional. ${ }^{21}$ Diante desse cenário, Menem conseguiu aprovar duas leis - lei de emergência administrativa e lei de emergência econômica - que contribuíram para seu "governo por decretos”. ${ }^{22}$ Em alguns decretos de necessidade e urgência, inclusive, sua legitimidade é reputada como questionável pelos analistas. ${ }^{23}$ Com a reforma constitucional de 1994 da Argentina, um dos objetivos pretendidos, conforme afirma Antonio Hernández, que exerceu a Vice-Presidência da Comissão de Redação da Convenção Nacional Constituinte, foi reduzir os níveis de hiperpresidencialismo no País, mas sua configuração política

\footnotetext{
${ }^{20}$ Ilustrando-se tal assertiva: "La democracia argentina, como hemos observado, de Alfonsín a Cristina Kirchner, puede ser definida como un sistema 'de un solo motor'. Presidencialismo puro, atenuado tímidamente por la reforma constitucional de 1994, con rasgos de hiper-presidencialismo durante el gobierno de Carlos Menem y evidenciando sus deficiencias clásicas durante el período interrumpido de Fernando de la Rúa (legitimidad dual, rigidez del mandato, sobrecarga de tensiones sobre el presidente, lógica del ganador único o 'suma cero', parálisis y crisis de governabilidad).” (BOSOER, Fabián. Ciclos electorales y ciclos políticos en la Argentina: 1983-2008: ¿Democracia ‘de uno o de dos motores’? Sociedad Global: Revista de Relaciones Internacionales y Ciencias Políticas, Vol. 3, 1, 2009. Disponível em: <http://www.eumed.net/rev/sg/03/fb.htm>. Acesso em: 23 dez. 2014.).

21 "Desde el inicio, el mandato de Menem se caracterizó por una fuerte concentración del poder en manos del Ejecutivo. El nuevo presidente supo aprovechar la amenaza de la crisis fiscal y de una hiperinflación galopante para justificar un estilo de gobierno por decretos, que se mantendría tras el periodo de emergencia. Los decretos de necesidad y urgencia no eran autorizados por la Constitución, pero personalidades oficiales proclamaban que la República Argentina se encontraba ante una emergencia económica que requería métodos drásticos para afrontarla, con el pretexto de que 'Mañana puede ser demasiado tarde.” (LEGRAIN, Milli. La crisis Argentina de diciembre de 2001: debilidad Institucional y falta de legitimidad del Estado. Serie Desarrollo y Coperación, 04-08, 2004. Disponível em: $<$ http://eprints.ucm.es/11249/1/WP08-04.pdf>. Acesso em: 8 jul. 2014. p. 7).

22 "Em meio à deterioração da vida econômica do país, o presidente Menem lançou mão de seus poderes de legislar por decreto e também conseguiu aprovar no congresso duas leis: a lei de emergência administrativa e a de emergência econômica para dar início às reformas. Estas medidas possibilitaram, logo no início de seu mandato, a realização de uma série de privatizações e vendas de serviços públicos como as linhas aéreas estatais, as empresas energéticas e de telecomunicações, além de permitir que o governo prosseguisse com as reformas em outros setores, como o financeiro, o comercial e quanto à legislação trabalhista.” (OLIVEIRA, Renata Peixoto. O Impacto do Sistema PolíticoInstitucional para as Reformas Neoliberais na Argentina, Chile e México. Teoria \& Sociedade, Vol. 16, 2, 2008. p. 193).

${ }^{23}$ “Importante ressaltar que no governo Menem, o expediente dos 'decretos de emergência' expedidos pelo Poder Executivo (alguns de duvidosa legalidade constitucional), em especial aqueles destinados a regular assuntos econômicos, foi amplamente usado para dar lastro às reformas e políticas que estavam sendo implementadas. De certa forma, a debilidade do Poder Legislativo argentino na década de 90 criou um cenário de 'hiper-presidencialismo' que apenas aprofundou, nas portas do século XXI, a noção por parte do povo argentino de que o governo Menem estava severamente envolvido em escândalos, permitindo o fortalecimento das condições que, somadas ao temerário cenário externo mencionado por Vadell, resultaram na grave crise econômica-institucional pela qual ainda passaria o País no início do primeiro decênio do século XXI.” (CAPANO, Fernando Fabiani. O Parlamento e as Crises na República Argentina: Apontamentos acerca do ferramental jurídico-constitucional do Poder Legislativo Argentino e seu comportamento nas crises das últimas décadas. In: CAGGIANO, Monica; GOMES, Karin (Org.). Tendências e Desafios do Constitucionalismo Latino-Americano. Cadernos de Pós-Graduação em Direito: estudos e documentos de trabalhos. São Paulo, SP: Comissão de Pós-Graduação da Faculdade de Direito da Universidade de São Paulo, 2011. p. $62)$.
} 
não permitiu que mudanças efetivas ocorressem. ${ }^{24}$ Nesse sentido, não seria possível atribuir somente ao período de Menem a qualidade de hiperpresidencialista. ${ }^{25}$

A história democrática mexicana indica uma forma peculiar de hiperpresidencialismo. Embora a Constituição Política dos Estados Unidos Mexicanos de 1917 não confira poderes normativos excepcionais a seu presidente, o sistema político do País conduziu a um longo período de "presidencialismo hegemônico". ${ }^{26}$ Ao contrário da maioria dos países latino-americanos, o presidente mexicano não possui poder de veto parcial, nem poder regulamentar, também interferindo pouco na agenda legislativa. ${ }^{27}$ Apesar de tais fragilidades normativas do presidente mexicano, alguns fatores podem ser apontados como responsáveis por seu protagonismo na política nacional, tais como a debilidade da atuação do Congresso e a falta de concorrência partidária. ${ }^{28} \mathrm{O}$

\footnotetext{
24 "Reiterando nuestro acuerdo con el diseño normativo realizado por la Convención, consideramos que por la falta de cumplimiento de la Constitución y permanente violación de la ley, no se ha verificado en el orden de la realidad una atenuación del hiper-presidencialismo como el constituyente lo legisló. [...] En particular, consideramos criticable la declinación por el Congreso de sus atribuciones, especialmente por la sanción de las leyes de emergencia económica como la 25.561, con amplísimas delegaciones legislativas, prorrogada hasta nuestros días; el uso excesivo de decretos de necesidad y urgencia y de legislación delegada por el Presidente; la concesión de los llamados superpoderes en la Administración financiera y presupuestaria al Jefe de Gabinete de Ministros y la práctica institucional de este último órgano, que en modo alguno ha atenuado los poderes presidenciales ni servido hasta ahora en una situación de crisis, como la de fines del 2001 durante la Presidencia de De la Rúa.” (HERNÁNDEZ, 2010, p. 188).

${ }^{25}$ Fortalecendo o argumento de que os governos mais recentes mantiveram a herança de Menem, Cristina Kirchner teria prorrogado pela sétima vez a lei de emergência pública da Argentina apenas dois dias após assumir seu posto na presidência, mesmo já restando superada a crise que outrora assolou o País em 2001 e 2002 (BOSOER, 2009).

26 “A história política recente mexicana foi marcada por um período de dominação de um grupo político sobre os demais, afastando tal país do panorama de pluralidade política que, de certa forma, surgiu na América Latina no início do século XX. Tal dominação, que se consagrou chamar de presidencialismo hegemônico representou uma real ausência de alternativas políticas ao partido dominante, o Partido Revolucionário Institucional (PRI), que reinou absoluto na cena política mexicana desde sua criação em 1929 até 2000, ocasião em que perdeu sua primeira eleição presidencial. Segundo José Luis Prado Maillard, Professor da Universidade de Nueva León, de fato, a causa simples para a manutenção, de tantas décadas, do 'presidencialismo hegemônico' foi o fato de não haver uma oposição apta a fazer frente ao poderio político do Governo e que pudesse representar uma alternativa eleitoral ao partido da situação. Giovanni Sartori, no mesmo sentido, aponta que o sistema partidário mexicano, desde a Revolução de 1910 e, em maior ou menor grau, até 2000, não se caracterizou pela competição eleitoral efetiva e pelo exercício real de oposição política, mecanismo essencial ao funcionamento da democracia. Tratou-se, segundo o autor, não de um sistema de partido predominante, mas sim de partido hegemônico.” (LAUANDOS, Artur Rega. O Parlamento Mexicano na Crise Latino Americana. In: CAGGIANO, Monica; GOMES, Karin (Org.). Tendências e Desafios do Constitucionalismo LatinoAmericano. Cadernos de Pós-Graduação em Direito: estudos e documentos de trabalhos. São Paulo, SP: Comissão de Pós-Graduação da Faculdade de Direito da Universidade de São Paulo, 2011. p. 21).

27 “ Con respecto al segundo aspecto - los poderes legislativos - las facultades constitucionales del Presidente mexicano son también relativamente moderadas. Carece de poder de decreto, puede vetar la totalidad de una ley aprobada por el Congreso pero no puede vetar partes de ella y promulgar el resto, y cuenta con relativamente pocos poderes de agenda legislativa, a diferencia de otros presidentes latinoamericanos que pueden imponer prioridades a los legisladores o enviarles proyectos de ley con carácter de urgencia.” (COLOMER, Josep. Reflexiones sobre la Reforma Política en México. In: CARBONELL, Miguel et al. Estrategias y propuestas para la reforma del Estado. Ciudad de Mexico, DF: Universidad Nacional Autónoma de México, 2002. Disponível em: <http://biblio.juridicas.unam.mx/libros/1/349/ 16.pdf>. Acesso em: 9 jul. 2014. p. 192).

28 "Primero. El control exclusivo del poder por un solo partido gracias a la ausencia de competencia política y el fraude electoral. Segundo. La faculdad del presidente en ejercicio de designar a su sucesor, así como a un alto número de candidatos a cargos públicos con elección casi asegurada. [...] Era la posibilidad de premio o castigo que se reservaba el presidente lo que le aseguraba el seguimiento de sus órdenes por los candidatos a cargos públicos hasta casi el final del mandato presidencial, ya que la lealtad al gran elector podía caducar en el mismo momento en que los designados
} 
contexto político posterior à criação do Partido Revolucionário Institucional (PRI) ficou caracterizado, devido à ausência de significativa oposição e concorrência partidárias, por seu absoluto predomínio no governo. Em 1988, a hegemonia deste partido foi abalada. Após décadas de controle supermajoritário do Congresso mexicano, o PRI deixou de contar com dois terços de apoio em ambas as casas legislativas. Embora a Cámara de Senadores ainda estivesse sob seu comando, com noventa por cento de apoio, o partido oficial do governo contava apenas com uma maioria simples na Cámara de Deputados (LUJAMBIO, 2001). A hegemonia se reverteu completamente no ano 2000, quando o Partido Acción Nacional (PAN) alcançou o governo e o PRI assistiu sua representação ser severamente reduzida. Independentemente da transição política mencionada acima, o presidente mexicano continua apresentando uma performance de destaque. Ilustrando-se tal contexto, o presidente mexicano controla a dinâmica orçamentária, tornando o Congresso mero coadjuvante na matéria por não haver mecanismo alternativo caso a proposta do Executivo não seja aprovada até o final do exercício financeiro - o que força os parlamentares a aprovar seu projeto a contragosto, temendo que o governo fique sem qualquer recurso disponível. ${ }^{29}$

O terceiro aspecto do fortalecimento do Poder Executivo na América Latina é o apoio ao governo recebido da população, admitindo-se que o grau maior ou menor de popularidade do presidente condicione sua atuação. A popularidade dos presidentes latino-americanos, em geral, sofre variações, como se pode observar no gráfico abaixo. ${ }^{30}$

ocuparan sus nuevos despachos. Tercero. La debilidad extrema del Congreso, convertido en un órgano de ratificación de las decisiones presidenciales. Los dos primeros elementos del hiperpresidencialismo - el control unipartidista y el dedazo presidencial - fueron eliminados a través de un proceso de democratización.” (COLOMER, 2002, p. 189-90).

29 "Existen fuertes restricciones para aprobar enmiendas al proyecto gubernamental, incluida la de que éstas no aumenten el déficit público, $\mathrm{y}$, de hecho, el presidente puede ampliar los gastos públicos sin aprobación del Congreso. México es el único país de América Latina en que, ante la hipótesis de que el Congreso no apruebe el presupuesto antes de fin de año, no existe una cláusula automática de prórroga del presupuesto anterior, por lo que la Federación podría quedarse temporalmente sin recursos disponibles. Así, el coste político del desacuerdo o del rechazo por el Congreso del proyecto gubernamental de presupuesto es muy alto, lo cual incentiva a los congresistas a aprobar alguna versión del mismo bajo la presión del calendario.” (COLOMER, 2002, p. 192).

${ }^{30}$ O gráfico é de elaboração própria, recorrendo, basicamente, aos dados do Informe 2013 da Corporación Latinobarómetro (CORPORACIÓN LATINOBARÓMETRO. Informe 2013. Santiago de Chile: Corporación Latinobarómetro, 2013. Disponível em: <http://www.latinobarometro.org/documentos/LATBD_INFORME_LB_ 2013.pdf>. Acesso em: 7 jun. 2014). Algumas informações, por apresentarem indícios de discrepância com o contexto correspondente à elaboração e à publicação do Informe 2013, foram contrastadas com outros referenciais. Os valores inseridos no gráfico concernentes ao Brasil e ao Uruguai não correspondem aos dados oficiais do Latinobarómetro. Como suas pesquisas se encerraram em junho de 2013, uma atualização se apresentou como indispensável em relação ao Brasil. Exatamente neste período o Brasil foi surpreendido por uma onda de protestos e reivindicações políticas que resultaram em um forte abalo na popularidade da então presidenta Dilma Rousseff. Os dados do Latinobarómetro indicavam uma popularidade de cinquenta e seis por cento, que, na verdade, foi drasticamente reduzido após esses eventos. Com base em outras pesquisas mais atualizadas, decidiu-se inserir o percentual de trinta e um por cento no gráfico (CONFEDERAÇÃO NACIONAL DO TRANSPORTE/MDA. Relatório Síntese - Rodada 114. Brasília, DF: Confederação Nacional do Transporte, 2013). Por fim, quanto ao Uruguai, o Latinobarómetro indicou um valor aparentemente discrepante do atual contexto: sessenta e um por cento de aprovação do presidente José Mujica. Este é um valor elevado e que, de fato, representa o primeiro ano do mandato de Mujica, em 2010. Porém, as pesquisas de opinião desenvolvidas no País indicam uma contínua queda em sua popularidade. A aprovação do presidente uruguaio 


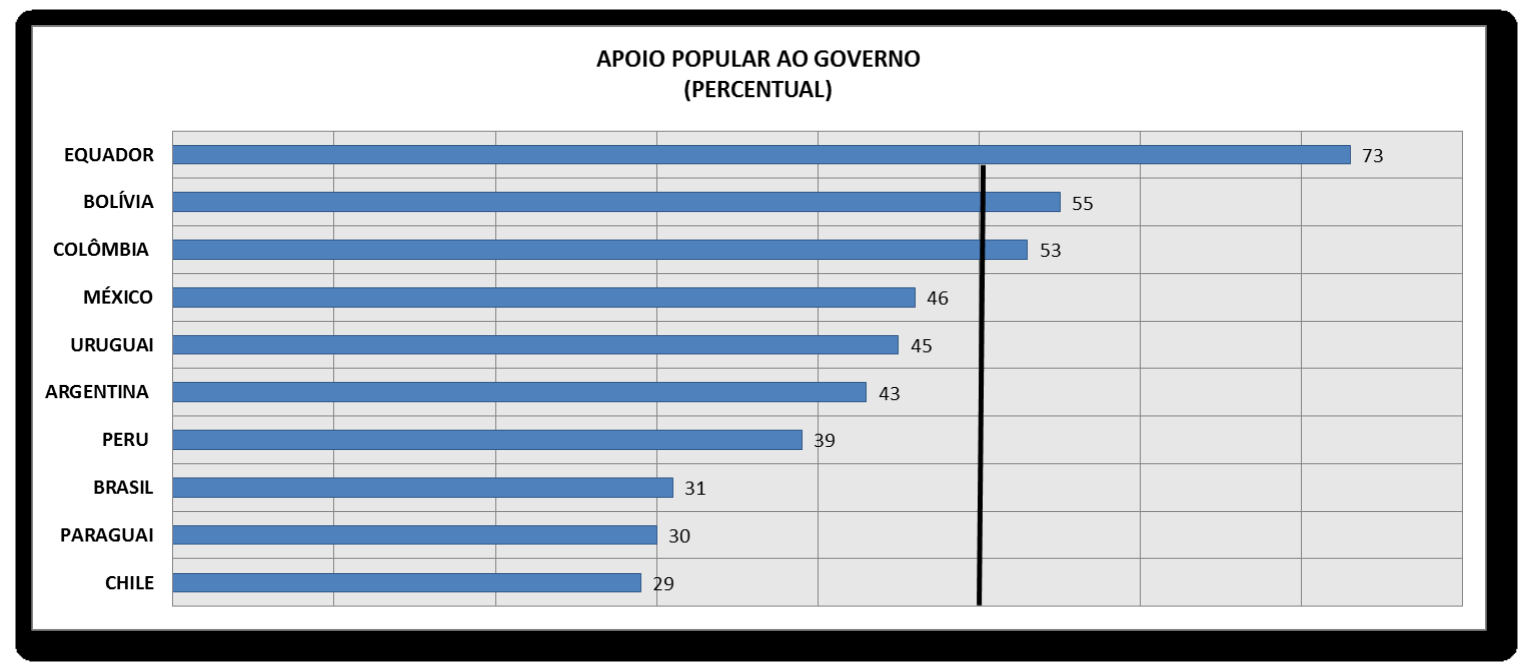

Embora os presidentes de metade dos países selecionados se concentrem na faixa entre trinta e um e quarenta e seis por cento do gráfico, a amplitude total encontrada é de quarenta e quatro pontos percentuais. Somente em três países - Equador, Bolívia e Colômbia - o nível de aprovação do presidente superou a metade dos valores percentuais. Em todos os demais, a popularidade encontra relativas dificuldades. A elevada popularidade dos presidentes equatoriano e boliviano pode ser relacionada a alguns fatores. Em primeiro lugar, esses dois países têm passado, ultimamente, por períodos de prosperidade e estabilidade econômicas pouco comuns. Em segundo lugar, seus líderes conduziram o processo de aprovação de novas constituições que passaram a garantir extensas listas de direitos sociais e a enfrentar com mais seriedade questões relacionadas aos povos originários, que compõem grande parte de suas populações. Além disso, trata-se de lideranças que têm explorado referendos e consultas públicas como instrumentos de governo, o que tende a gerar satisfação dos cidadãos quanto às decisões implementadas. A elevada popularidade do presidente colombiano, no entanto, tem origem em outros aspectos. O apoio popular ao governo colombiano ganhou maior expressão quando Álvaro Uribe se candidatou à presidência mediante um plano de oposição às Forças Armadas Revolucionárias Colombianas (Farc). ${ }^{31}$ Ao levantar esta bandeira, Uribe conquistou popularidade e venceu as eleições presidenciais de 2002, permanecendo no posto até 2010. Com o término de seu mandato, Uribe foi substituído por Juan Manuel Santos,

em 2013 manteve-se por volta de quarenta e cinco por cento, conforme indicado constantemente pelas pesquisas da empresa de consultoria uruguaia Cifra. Disponível em: <http://www.cifra.com.uy/novedades.php?idNoticia=204>. Acesso em: 09 de julho de 2014.

${ }^{31}$ Cf. ARISTIZÁBAL, Luis Guillermo Patiño; RESTREPO, Porfirio Cardona. El neopopulismo: una aproximación al caso colombiano y venezolano. Estudios Políticos, n 34, enero-junio, 2009. Nesse artigo, sustenta-se que esta estratégia adotada por Uribe teve especial relevância para implementar um regime hiperpresidencialista na Colômbia. 
que preferiu adotar uma política de apaziguamento com as Farc, mas o apoio popular ao governo ainda se mantém estável.

Analisando-se isoladamente o gráfico acima, é possível ressaltar que o Equador é o único país a se destacar nos três aspectos admitidos na avaliação do fortalecimento do Executivo. O hiperpresidencialismo desse país é, portanto, marcante. Essa não é, todavia, a única informação que pode ser extraída. Alguns países frequentemente designados hiperpresidencialistas - seja no meio acadêmico ou mesmo na mídia - não haviam se destacado durante a análise dos demais aspectos. Os presidentes da Bolívia e da Colômbia, especialmente o primeiro, devem grande parte de sua governabilidade ao apoio que recebem da população. O presidente equatoriano, por sua vez, conta com outros recursos além de sua ampla adesão popular. Outros países latino-americanos que apresentaram uma performance inquestionavelmente hiperpresidencialista, ao contrário, pouco se destacaram no gráfico. Países como México e Argentina foram capazes de manter uma performance digna de ênfase ao mesmo tempo que não se destacaram com a mesma proporção nos aspectos poderes constitucionais e apoio popular ao governo. De maneira mais marcante, Brasil e Chile, países que exploram um sistema de coalizão de partidos, apresentaram quantitativos reduzidos neste último quesito, mas não aparentam ter perdido a qualidade de hiperpresidencialista.

Uma vez analisados os principais aspectos relacionados ao fortalecimento do Poder Executivo na América Latina, esses resultados obtidos devem ser convertidos em indicativos mais simples e objetivos. Isso permite uma comparação mais adequada destes dados com aqueles extraídos da avaliação das mudanças constitucionais na Região. Os métodos para tanto utilizados se orientam por atribuir a devida importância a cada um dos aspectos apreciados sem prejudicar a uniformidade das análises dos dez países selecionados pela pesquisa. Após a elaboração do IFEXEC, será possível comparar os governos latino-americanos entre si, bem como confrontar tais informações com aquelas que decorreram da construção do Índice de Mudança Constitucional (IMCONST). Nesse sentido, optou-se por atribuir valores ao fortalecimento do Executivo em uma escala de zero a três, admitindo-se fracionamentos de até duas casas decimais, firmando-se um paralelo com aquele índice.

O índice correspondente ao fortalecimento do Poder Executivo - IF-EXEC - atende a seis regras de indexação. Em geral, cada um dos três aspectos do fortalecimento do Executivo analisados - poderes constitucionais, configuração política e apoio popular ao governo corresponde a uma variável deste índice: $x, y$ e $z$. Duas regras - a quarta e a quinta - destinam-se ao contrabalanceamento destes valores para que os índices reflitam informações mais realistas e fidedignas. A primeira regra determina uma classificação dos poderes constitucionais do país para 
obter o valor da variável $x$. Nos casos em que tais prerrogativas não fogem à normalidade, o país receberá meio ponto; naqueles em que a constituição notadamente franqueia ao Executivo expressivos poderes, como veto total e parcial, regulamentar, de agenda, de iniciativa de lei ou emenda constitucional, entre outros, atribui-se o valor de um ponto. A segunda regra, por sua vez, classifica a performance do Executivo diante da configuração política do país. Quando o efetivo desempenho do presidente permite uma proeminência marcante em sua relação com o Legislativo, a variável y recebe um ponto, enquanto performances mais tímidas lhe concederão meio ponto apenas. A terceira regra promove uma classificação do apoio popular ao governo, atribuindo-se um ponto à variável $z$ àqueles países que alcançam popularidade superior a cinquenta por cento e meio ponto nos demais casos. Antes de esclarecer as regras seguintes, poderes constitucionais, configuração política e apoio popular são aspectos que contribuem ao fortalecimento do Executivo, porém, em níveis distintos de relevância. Por esta razão, as variáveis correspondentes também receberão pesos distintos. A performance política do presidente parece ser o fator mais determinante ao hiperpresidencialismo, uma vez que pode contrariar a lógica estabelecida pelos poderes constitucionais, seguida da aprovação popular. Seguindo-se esta ordem, a quarta regra submete o valor da variável $x$ pelo divisor dois, enquanto a quinta regra submete a variável $y$ ao multiplicador um ponto e meio - nenhum divisor ou multiplicador é aplicado à variável z. Com a sexta regra, por fim, são somados os resultados, encontrando-se um valor na escala de zero a três, correspondente ao fortalecimento do Executivo de cada país.

De acordo com as análises empreendidas pela presente pesquisa, destacaram-se nas variáveis $x, y$ e z: Brasil, Equador e Peru (variável x); Brasil, Chile, Argentina, México e Equador (variável y); e Colômbia, Bolívia e Equador (variável z). ${ }^{32}$ Atendidas as três primeiras regras de indexação, os valores devem ser consolidados de acordo com o divisor da variável $x$ e 0 multiplicador da variável y e somados. A fórmula abaixo sintetiza tais operações.

$$
\mathrm{IF}_{\mathrm{EXEC}}=\left(\frac{x}{2}\right)+(y \cdot 1,5)+z
$$

Com a aplicação da fórmula acima aos valores preliminares indicados na tabela, o material consolidado corresponde ao IF-EXEC de cada país. A fórmula, que sintetiza as regras de indexação,

\footnotetext{
32 Os resultados parciais da sondagem dos países latino-americanos, antes da aplicação das regras de contrabalanceamento da indexação, podem ser expostos da seguinte maneira: Paraguai $(x: 0,5 ; y$ : 0,5 ; $z$ : 0,5$)$; Uruguai: (x: 0,5; y: 0,5; z: 0,5); Colômbia: (x: 0,5; y: 0,5; z: 1); Brasil: (x: 1 ; y: 1; z: 0,5); Chile: (x: 0,5; $y: 1$; z: 0,5); Argentina: (x: 0,5; y: 1; z: 0,5); México: (x: 0,5; y: 1; z: 0,5); Bolívia: (x: 0,5; y: 0,5; z: 1); Equador: $(x: 1 ; y: 1 ; z: 1)$; e Peru: (x: 1; y: $0,5 ; z: 0,5)$.
} 
depois de aplicada, permite um balanceamento do que se julga serem os principais aspectos do fortalecimento do Poder Executivo na América Latina. Tais operações conduzem aos resultados dispostos no gráfico que segue. ${ }^{33}$

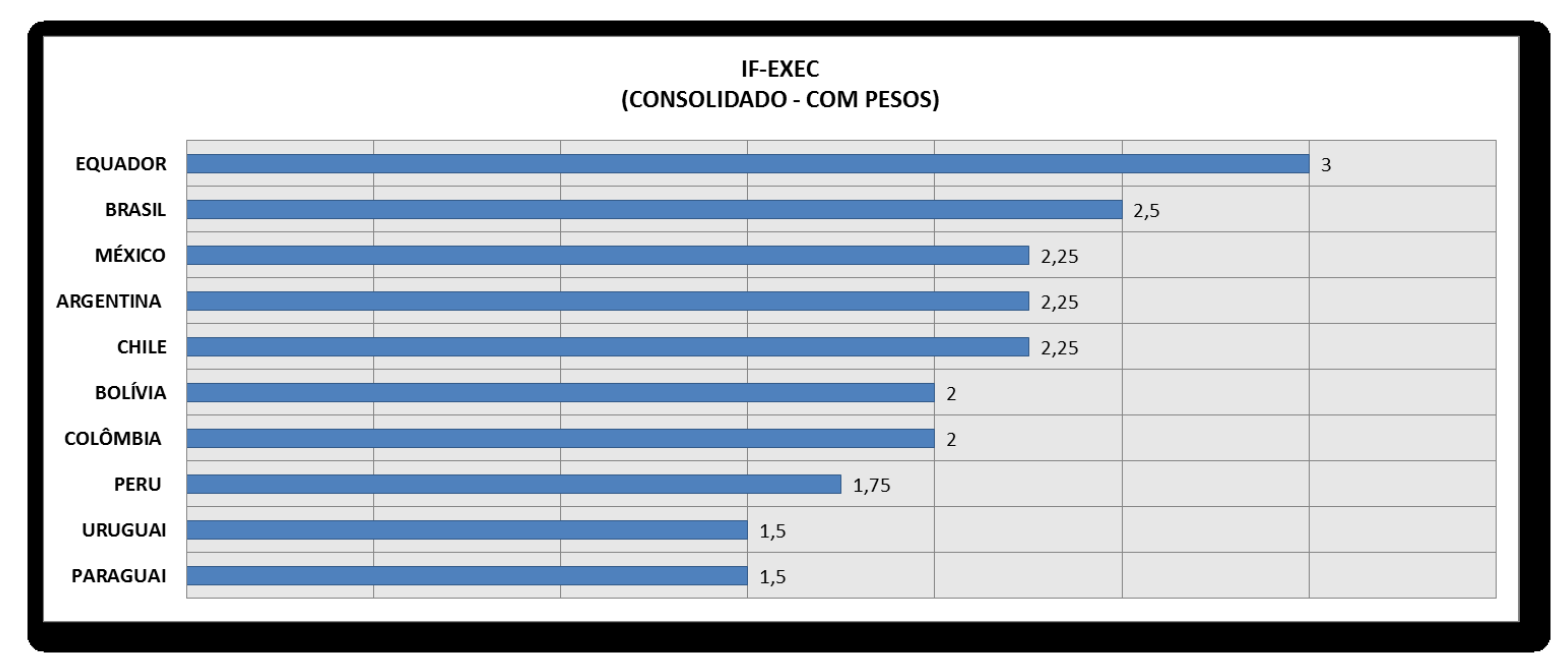

O gráfico acima pode ser dividido em três segmentos. O primeiro segmento, contendo os países cujos índices sejam inferiores a dois inteiros, representa os governos que não apresentam um modelo de fortalecimento acentuado do Executivo. Ao se abordarem países como Peru, Uruguai e Paraguai - sobretudo estes últimos -, o uso do termo hiperpresidencialismo em sua avaliação tornase questionável após a consolidação dos resultados. No segundo segmento, em que os índices são não inferiores a dois inteiros e inferiores a dois inteiros e meio, encontram-se cinco dos dez países latino-americanos analisados. Com isso, seria plausível sustentar que se trata de um padrão mediano de fortalecimento do Poder Executivo na América Latina, representado por México, Argentina, Chile, Bolívia e Colômbia. Por fim, no último segmento, referente àqueles não inferiores a dois inteiros e meio, restam Brasil e Equador. Nesses dois países, o nível de fortalecimento do Executivo é mais expressivo e, portanto, assume características alarmantes, principalmente no caso equatoriano.

\section{MUDANÇA CONSTITUCIONAL E HIPERPRESIDENCIALISMO}

Após uma análise individualizada do fortalecimento do Poder Executivo nos países latinoamericanos objetos dessa pesquisa, alguns dados podem ser cruzados para que se extraiam resultados comparativos de maior relevância e com maior precisão. Como ressaltado no início do

\footnotetext{
${ }^{33}$ Gráfico de elaboração própria.
} 
texto, esse cruzamento de dados depende de informações produzidas a partir do Índice de Mudança Constitucional (IM-CONST). ${ }^{34} \mathrm{O}$ gráfico disposto abaixo permite uma comparação entre o fortalecimento dos presidentes latino-americanos e a mudança constitucional. ${ }^{35} \mathrm{Em}$ geral, algumas proporcionalidades podem ser encontradas no gráfico abaixo. ${ }^{36}$

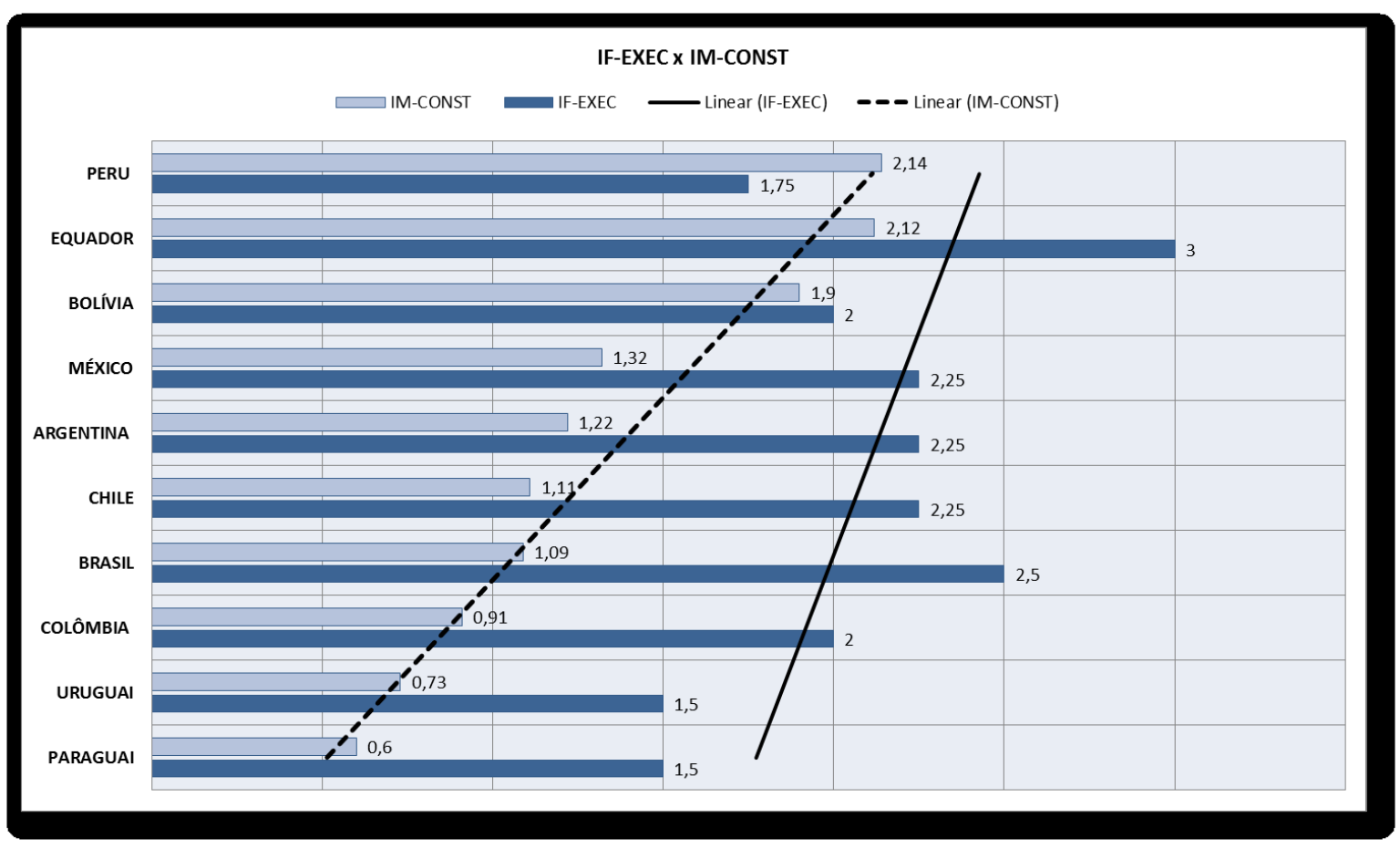

O gráfico comparativo acima demonstra a existência de uma associação entre o quanto os países passam por mudanças constitucionais e a forma como seus presidentes se fortalecem. Em geral, quanto mais o país passa por mudanças constitucionais, mais intenso tende a ser seu processo de fortalecimento do Poder Executivo. As linhas de tendência inseridas para cada índice ilustram como tais fenômenos, em termos amplos, acompanham-se e formam um padrão.

Esse padrão pode se tornar mais preciso por meio do cálculo de uma razão entre os índices. Dividindo-se o valor do IM-CONST pelo do IF-EXEC em cada país, o que se obtém é uma variação inferior a dois décimos, confirmada em sete dos dez países avaliados: Paraguai, Uruguai, Colômbia, Brasil, Chile, Argentina e México. ${ }^{37}$ Nesses países latino-americanos, a hipótese formulada

\footnotetext{
${ }^{34}$ O IM-CONST foi elaborado em artigo diverso, denominado Mudança Constitucional na América Latina, ainda em avaliação.

${ }^{35}$ Gráfico de elaboração própria.

${ }^{36}$ Gráfico de elaboração própria.

${ }^{37}$ As razões encontradas, admitindo-se fracionamentos de até duas casas decimais, são as seguintes: Paraguai $(0,4)$; Uruguai (0,49); Colômbia (0,46); Brasil (0,44); Chile (0,49); Argentina (0,54); México (0,59); Bolívia (0,95); Equador $(0,71)$; e Peru (1,22). O padrão somente não se mantém em relação à Bolívia, ao Equador e ao Peru.
} 
inicialmente parece restar assegurada com maior facilidade, uma vez que a associação entre os indicativos de mudança constitucional e de fortalecimento do Poder Executivo é evidente.

O fato de o padrão não se reproduzir nos outros três países, entretanto, não descarta a possibilidade de confirmação da hipótese também nestes países. A Bolívia, muito embora apresente um padrão distinto dos demais países latino-americanos, apresenta valores quase idênticos nos dois índices: um inteiro e nove décimos no IM-CONST e dois inteiros no IF-EXEC. Com isso, o terceiro país latino-americano, dentre os integrantes desta pesquisa, que mais sofreu mudanças constitucionais, também manifesta características hiperpresidencialistas. O Equador, ao longo de toda a pesquisa, comportou-se de modo excepcional, não se submetendo a qualquer parâmetro de normalidade. De acordo com as análises promovidas, o segundo país latino-americano que mais passou por mudanças constitucionais é, evidentemente, o mais hiperpresidencialista. No particular caso equatoriano, o atendimento a algum padrão é que seria um fato realmente surpreendente. Por fim, o Peru não se comportou de acordo com os padrões latino-americanos, sendo o único país que demonstrou ter sofrido mais mudanças constitucionais do que fortalecimento do seu Poder Executivo. O Peru, no entanto, merece ressalvas quanto a seus valores no IM-CONST. Trata-se de um país que, historicamente, alterou severamente suas constituições, mas, durante os séculos XX e XXI, somente observou o advento de quatro constituições. Além disso, apenas reformou sua atual constituição, que superou vinte anos de vigência, em onze oportunidades. Tais informações esclarecem que, no Peru, a duração média de suas constituições no século XX - considerando que a atual é de 1993 - é de vinte e quatro anos, e o tempo médio exigido para reformar a atual constituição é de vinte e três meses - quase dois anos completos sem reformas. O histórico recente peruano, portanto, é mais compatível com os países que pouco se submetem a mudanças constitucionais, tais como Paraguai, Uruguai e Colômbia. A partir desta revisão, é possível constatar que a excepcional trajetória constitucional peruana não se distancia tanto dos valores atribuídos a seu índice de fortalecimento do Executivo.

Mesmo nos três países que não refletem o padrão latino-americano na razão entre o IMCONST e o IF-EXEC, os distanciamentos são justificáveis, não contestando a hipótese sustentada. Nos dez países apreciados pela pesquisa, sete indicam uma evidente associação entre as proporções de mudanças constitucionais suportadas e o fortalecimento do Poder Executivo constatado. Nos demais casos, a relação ainda assim parece confirmada de acordo com os argumentos sustentados acima. 


\section{CONCLUSÃO}

A presente pesquisa adotou como seu objeto de análises os processos de fortalecimento do Poder Executivo na América Latina. Basicamente, esse objeto foi apreciado em dez países latinoamericanos, para avaliar se o posicionamento do "novo constitucionalismo latino-americano", antagônico à figura do presidente e a seus governos hiperpresidencialistas, estaria adequado ao celebrar e fomentar processos de mudança constitucional na Região.

Ao final das análises, parece ser plausível julgar a hipótese como confirmada, uma vez que os resultados da pesquisa apontam à existência de uma associação entre as mudanças constitucionais e o fortalecimento dos presidentes na América Latina. Quanto a essa conclusão, é digno de especial destaque o fato de que se defende simplesmente uma associação entre tais processos.

Os esforços da presente pesquisa não foram direcionados à tentativa de comprovar qualquer relação de causalidade entre o fortalecimento apontado e os processos de mudança constitucional. A confirmação da hipótese não implica afirmar que mudanças constitucionais ocorrerem por causa do fortalecimento do Executivo, nem mesmo o contrário. Embora não se negue a possibilidade de um processo, em alguma medida, influenciar o outro, uma relação desta qualidade exigiria o estabelecimento de metodologia própria. Por um lado, é possível que alguns presidentes aproveitem oportunidades de fortalecimento em meio à insegurança jurídica ocasionada pelo advento de uma nova constituição. Isso pode ser ilustrado pelos casos do México após 1917, do Brasil após 1988 e da Bolívia após 2009. Por outro lado, é ainda mais comum na história constitucional latino-americana que mudanças constitucionais reflitam uma transição política operada por um governo centralizador. Neste caso, há exemplos relacionados a governos autoritários, como observado na Argentina em 1956, 1966, 1972 e 1976, no Chile entre 1980 e 1989, e no Peru em 1993, assim como em regimes democráticos, tais como na Argentina após 1994 e no Equador após 2008. De qualquer modo, o que se buscou sustentar foi, simplesmente, que, no contexto latino-americano, mudança constitucional e fortalecimento do Poder Executivo são processos que se acompanham.

A crítica direcionada ao "novo constitucionalismo latino-americano” exposta no presente trabalho pode ser sintetizada da seguinte forma: diante da associação aqui defendida, a postura apologética às mudanças constitucionais, quando simultânea à indiferença ou à oposição oferecida em relação ao hiperpresidencialismo da Região, aparenta uma inconsistência teórica do "novo constitucionalismo latino-americano”. 


\section{REFERÊNCIAS}

ABRANCHES, Sérgio. Presidencialismo de coalizão: o dilema institucional brasileiro. Dados Revista de Ciências Sociais, Vol. 31, 1, 1988.

ARISTIZÁBAL, Luis Guillermo Patiño; RESTREPO, Porfirio Cardona. El neopopulismo: una aproximación al caso colombiano y venezolano. Estudios Políticos, nº 34, enero-junio, 2009.

BALDI, César Augusto. Novo constitucionalismo Latino-Americano: considerações conceituais e discussões epistemológicas. In: WOLKMER, Antonio Carlos; CORREAS, Oscar (Coord.). Crítica Jurídica en América Latina. Aguascalientes/Florianópolis: Centro de Estudios Jurídicos y Sociales Mispatt/UFSC, 2013.

BASSABE-SERRANO, Santiago. Ecuador: Reforma Constitucional, Nuevos Actores Políticos y Viejas Práticas Partidistas. Revista de Ciência Política, Vol. 29, nº 2, 2009.

BICKEL, Alexander. The Least Dangerous Branch: The Supreme Court at the Bar of Politics. New Haven, CT: Yale University Press, 1962.

BOSOER, Fabián. Ciclos electorales y ciclos políticos en la Argentina: 1983-2008: ¿Democracia 'de uno o de dos motores'? Sociedad Global: Revista de Relaciones Internacionales y Ciencias Políticas, Vol. 3, 1, 2009. Disponível em: <http://www.eumed.net/rev/sg/03/fb.htm>. Acesso em: 23 dez. 2014.

CAPANO, Fernando Fabiani. O Parlamento e as Crises na República Argentina: Apontamentos acerca do ferramental jurídico-constitucional do Poder Legislativo Argentino e seu comportamento nas crises das últimas décadas. In: CAGGIANO, Monica; GOMES, Karin (Org.). Tendências e Desafios do Constitucionalismo Latino-Americano. Cadernos de Pós-Graduação em Direito: estudos e documentos de trabalhos. São Paulo, SP: Comissão de Pós-Graduação da Faculdade de Direito da Universidade de São Paulo, 2011.

CARBONELL, Miguel. Neoconstitucionalismo(s). $4^{\text {a }}$ ed. Madrid: Trotta, 2009.

COLOMER, Josep. Reflexiones sobre la Reforma Política en México. In: CARBONELL, Miguel et al. Estrategias y propuestas para la reforma del Estado. Ciudad de Mexico, DF: Universidad Nacional Autónoma de México, 2002. Disponível em: <http://biblio.juridicas.unam.mx/libros/1/ 349/16.pdf>. Acesso em: 9 jul. 2014.

CONFEDERAÇÃO NACIONAL DO TRANSPORTE/MDA. Relatório Síntese - Rodada 114. Brasília, DF: Confederação Nacional do Transporte, 2013.

CORPORACIÓN LATINOBARÓMETRO. Informe 2013. Santiago de Chile: Corporación Latinobarómetro, 2013. Disponível em: <http://www.latinobarometro.org/documentos/LATBD_ INFORME_LB_2013.pdf>. Acesso em: 7 jun. 2014.

GARGARELLA, Roberto. "Piedras de papel” y silencio: la crisis política argentina leída desde su sistema institucional. Disponível em: <http://www.cels.org.ar/common/documentos/2002_ dossier1.pdf>. Acesso em: 22 jun. 2014. 
Latin american constitutionalism, 1810-2010. The engine room of the Constitution. New York, NY: Oxford University Press, 2013.

HERNÁNDEZ, Antonio. A Tres Lustros de la Reforma Constitucional de 1994. Revista de la Faculdad de Derecho de México, Vol. 60, 254, 2010.

HUNEEUS, Carlos. Variedades de Governos de Coalizão no Presidencialismo. Chile, 1990-2000. Dados - Revista de Ciências Sociais, Vol. 55, 4, 2012.

LAUANDOS, Artur Rega. O Parlamento Mexicano na Crise Latino Americana. In: CAGGIANO, Monica; GOMES, Karin (Org.). Tendências e Desafios do Constitucionalismo Latino-Americano. Cadernos de Pós-Graduação em Direito: estudos e documentos de trabalhos. São Paulo, SP: Comissão de Pós-Graduação da Faculdade de Direito da Universidade de São Paulo, 2011.

LEGRAIN, Milli. La crisis Argentina de diciembre de 2001: debilidad Institucional y falta de legitimidad del Estado. Serie Desarrollo y Coperación, 04-08, 2004. Disponível em: $<$ http://eprints.ucm.es/11249/1/WP08-04.pdf>. Acesso em: 8 jul. 2014.

LUJAMBIO, Alonso. Adiós a la excepcionalidad: régimen presidencial y gobierno dividido en México. In: LANZARO, Jorge (Comp.). Tipos de presidencialismo y Coaliciones Políticas en América Latina. Buenos Aires: CLACSO, 2001.

MAINWARING, Scott; SHUGART, Matthew. Presidentialism and Democracy in Latin America. Cambridge, MA: Cambridge University Press, 1997.

MOISÉS, José Álvaro. O desempenho do Congresso Nacional no presidencialismo de coalizão. In: MOISÉS, José Álvaro (Org.). O Papel do Congresso Nacional do Presidencialismo de Coalizão. Rio de Janeiro, RJ: Konrad-Adenauer-Stiftung, 2011.

NINO, Carlos Santiago. Fundamentos de derecho constitucional: análisis filosófico, jurídico y politológico de la práctica constitucional. Buenos Aires: Astrea, 1992.

OLIVEIRA, Renata Peixoto. O Impacto do Sistema Político-Institucional para as Reformas Neoliberais na Argentina, Chile e México. Teoria \& Sociedade, Vol. 16, 2, 2008.

PASTOR, Roberto Viciano; DALMAU, Rúben Martínez. ¿Se puede hablar de un nuevo constitucionalismo latinoamericano como corriente doctrinal sistematizada? 2010. Disponível em: <http://www.juridicas.unam.mx/wccl/ponencias/13/245.pdf>. Acesso em: 7 jun. 2014.

POSNER, Eric; VERMEULE, Adrian. The Executive Unbound: after the madisonian republic. New York: Oxford University Press, 2010.

SCHLESINGER, JR., Arthur. The Imperial Presidency. New York, NY: The Mariner Books, 2004.

SHUGART, Matthew; CAREY, John. Presidents and Assemblies: Constitutional Design and Electoral Dynamics. Cambridge, MA: Cambridge University Press, 1992.

SUNSTEIN, Cass; VERMEULE, Adrian. Interpretation and Institutions. Chicago Public Law \& Legal Theory Working Paper Series, N. 28, 2002. 
UPRIMNY, Rodrigo. Las transformaciones constitucionales recientes en América Latina: tendencias y desafios. In: RODRÍGUEZ GARAVITO, César (Coord.). El Derecho en América Latina: un mapa para el pensamiento jurídico del siglo XXI. Buenos Aires: Siglo Veintiuno, 2011. Disponível em: <www.juridicas.unam.mx/wccl/ponencias/13/242.pdf>. Acesso em: 21 fev. 2015.

\title{
HYPER-PRESIDENTIALISM IN LATIN AMERICA
}

\begin{abstract}
This article adopts the Executive branch's strengthening processes as its object. The methodology cares to the Latin America delimitation among others aspects. The main problem found is the antagonism between this strengthening and the constitutional change in the region according to the called "Latin American new constitutionalism". In this movement, the celebration of constitutional changes in the region is characteristic, likewise in the Bolivian and Ecuadorian Constitutions approval in 2008 and 2009. The president, however, does not receive the same weight as parliamentarians and judges. Their governments, when not treated with indifference, suffer accusations of hyperpresidentialism, labeled as a Latin America "institutional pathology". Thus, the hypothesis of this research argues the existence of an association between constitutional change and Executive branch's strengthening processes in the region. Beginning with an institutionalist theoretical framework, the aim of this work is to provide a critique of the "Latin American new constitutionalism", because its defense of Latin America constitutional changes should not ignore the strengthening of their presidents associated with that process.
\end{abstract}

PALAVRAS-CHAVE: América Latina. Desenhos Constitucionais. Hiperpresidencialismo. Mudança Constitucional. Novo Constitucionalismo Latino-Americano.

Recebido: 23 de dezembro de 2014

Aprovado: 23 de fevereiro de 2015 